Article

\title{
Evaluation of Reliable Digital Elevation Model Resolution for TOPMODEL in Two Mountainous Watersheds, South Korea
}

\author{
Daeryong Park ${ }^{1}{ }^{(}$, Huan-Jung Fan ${ }^{2}$, Jun-Jie Zhu ${ }^{3}{ }^{\circledR}$, Sang-Eun $\mathrm{Oh}^{4}$, Myoung-Jin $\mathrm{Um}^{5}{ }^{5}$ and \\ Kichul Jung ${ }^{1, *}$ \\ 1 Department of Civil and Environmental Engineering, Konkuk University, 120 Neungdong-ro, Gwangjin-gu, \\ Seoul 05029, Korea \\ 2 Department of Safety, Health and Environmental Engineering, Hungkuang University, \\ Taichung 43302, Taiwan \\ 3 Department of Civil, Architectural and Environmental Engineering, Illinois Institute of Technology, \\ Chicago, IL 60616-3793, USA \\ 4 Department of Biological Environment, Kangwon National University, 192-1 Hyoja-2-dong, Gangwondo, \\ Chuncheon 200-701, Korea \\ 5 Department of Civil Engineering, Kyonggi University, 154-42 Gwanggyosan-ro, Yeongtong-gu, \\ Suwon 16227, Korea \\ * Correspondence: jkichul11@konkuk.ac.kr
}

Received: 8 June 2019; Accepted: 3 September 2019; Published: 5 September 2019

\begin{abstract}
This study analyzed the result of parameter optimization using the digital elevation model (DEM) resolution in the TOPography-based hydrological MODEL (TOPMODEL). Also, this study investigated the sensitivity of the TOPMODEL efficiency by applying the varying resolution of the DEM grid cell size. This work applied TOPMODEL to two mountainous watersheds in South Korea: the Dongkok watershed in the Wicheon river basin and the Ieemokjung watershed in the Pyeongchang river basin. The DEM grid cell sizes were 5, 10, 20, 40, 80, 160, and $300 \mathrm{~m}$. The effect of DEM grid cell size on the runoff was investigated by using the DEM grid cell size resolution to optimize the parameter sets. As the DEM grid cell size increased, the estimated peak discharge was found to increase based on different parameter sets. In addition, this study investigated the DEM grid cell size that was most reliable for use in runoff simulations with various parameter sets in the experimental watersheds. The results demonstrated that the TOPMODEL efficiencies in both the Dongkok and Ieemokjung watersheds rarely changed up to a DEM grid-size resolution of about $40 \mathrm{~m}$, but the TOPMODEL efficiencies changed with the coarse resolution as the parameter sets were changed. This study is important for understanding and quantifying the modeling behaviors of TOPMODEL under the influence of DEM resolution based on different parameter sets.
\end{abstract}

Keywords: DEM grid cell size; efficiency; mountainous watersheds; optimized parameter set; TOPMODEL

\section{Introduction}

Rainfall-runoff relationships are generally simulated using a simplified conceptual model based on physical processes. Conventionally, this process involves the use of a lumped model, which considers the watershed as a homogenous element. The lumped model assumes that the watershed is a single black box that is highly dependent on the reliability of rainfall and runoff data; it suffers from the disadvantage that the temporal and spatial transformations of the rainfall to runoff are not explicitly considered. The development of Geographic Information Systems has facilitated the development of a 
dynamic model for analyzing the runoff phenomena and has allowed the development of a distributed parameter model that considers the spatial variability of parameters related to the runoff process. It focuses on the spatial variability of the process and explains the physical relationship between the topographic and runoff model parameters by analyzing the runoff.

To analyze the runoff event pattern using computational watershed models, the input parameters should be accurately estimated by reflecting the hydrological and hydraulic conditions such as the topographic characteristics, rainfall, and infiltration. However, accurately simulating the rainfall-runoff event is difficult because of the nonlinear characteristics of natural phenomena. One of the distributed parameter models developed to overcome these limitations is the TOPography-based hydrological MODEL (TOPMODEL), which uses the digital elevation model (DEM) [1]. TOPMODEL is semidistributed watershed model and has mainly been applied to hydrologic simulations in mountain basins [2-6]. TOPMODEL has the advantage in that it can easily separate surface runoff from basal runoff, and a runoff simulation can be performed for a long period. Similarly, the variable infiltration capacity (VIC) model can simulate rainfall-runoff processes and separates surface runoff and baseflow using the concept of three layers [7,8]. The VIC model simulates both water- and energy-balance equations and considers land-cover type as well as the concept of three soil layers. In contrast, TOPMODEL has a physical basis and focuses on hydrologic processes. Furthermore, the two models employ different infiltration estimation methods. TOPMODEL applies the Green Amp equation, whereas the VIC model uses various empirical methods [9].

Beven and Kirby [1] proposed TOPMODEL as a distributed parameter model for a runoff-contributing area. Beven and Wood [10] analyzed the effects of watershed topography on a river runoff using TOPMODEL. The influences of the spatial scale of the DEM, and the topographic characteristics on the hydrological process in TOPMODEL have been studied [11-14]. Saulnier et al. $[15,16]$ analyzed the influence of permeability coefficient based on the DEM resolution. When the DEM resolution is larger, the permeability coefficient accordingly increases, and the variation in the coefficient is smaller.

To date, many researchers have pointed out that the topographic index in TOPMODEL is affected by the DEM resolution [17-19]. They usually demonstrated that high DEM resolutions can yield accurate topographic index estimates [20-22]. However, the effects of optimized input parameters based on the resolution of topographic data (e.g., effects of changes in DEM grid cell size), as well as the concept of reliable DEM grid cell size resolution on experimental watersheds in TOPMODEL have been rarely studied. In particular, Lin et al. [23] investigated the influence of DEM resolution in TOPMODEL in the Hanjiang River, China, and reported no evident differences in the uncertainty intervals corresponding to different DEM resolutions represented in TOPMODEL. However, uncertainty intervals corresponding to different DEM resolutions depending on changing input parameters in TOPMODEL have not yet been clarified. The objective of this study is to suggest a reliable DEM grid-size resolution that exhibits a low sensitivity to change in the input parameters during runoff simulations in experimental watersheds. To this end, this study attempted (1) to investigate the effects of DEM grid cell size on the simulated runoffs during the application of different optimized input parameters, and (2) to investigate the effects of DEM grid cell size on the simulated runoffs when a constant input parameter set is applied.

\section{Geographical Setting and Morphometry of the Study Area}

TOPMODEL was applied as a conceptual distributed runoff model to generate runoffs in the target watersheds. TOPMODEL considered the topographic factors estimated by DEM in the watershed. This study investigated two mountainous watersheds, namely, the Dongkok and Ieemokjung watersheds, using TOPMODEL, as shown in Figure 1. The Dongkok watershed is located upstream of the Wicheon river, a tributary of the Nakdong River, and contains one rain- and a number of streamflow-gauge stations. Similarly, the Ieemokjung watershed is a subcatchment of the Pyeongchang River, a tributary 
of the South Han River, and contains one rain- and one streamflow-gauge station. Figure 1 shows the locations of the rain- and streamflow-gauge stations in the Dongkok and Ieemokjung watersheds.

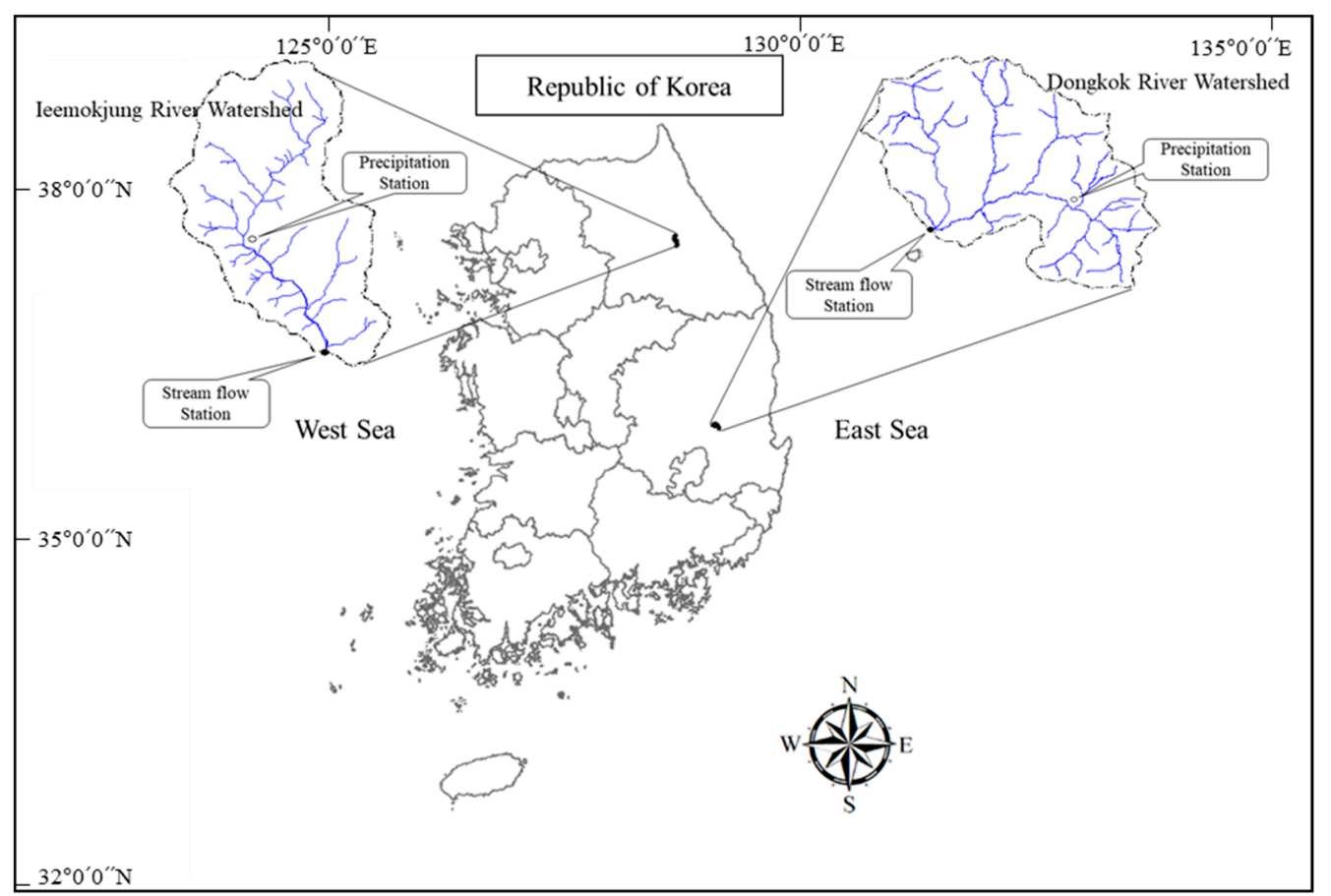

Figure 1. Location of the Dongkok (Lat: $36^{\circ} 07^{\prime} 11^{\prime \prime} \mathrm{N}$, Lon: $128^{\circ} 47^{\prime} 46^{\prime \prime} \mathrm{E}$ ) and Ieemokjung (Lat: $37^{\circ} 37^{\prime} 17^{\prime \prime}$ N, Lon: $128^{\circ} 28^{\prime} 19^{\prime \prime}$ E) watersheds in South Korea.

Table 1 lists the topographical and morphological characteristics of the Dongkok and Ieemokjung watersheds. The drainage area, river length, and main tributary length in the leemokjung watershed are larger than those in the Dongkok watershed. However, the mean width of the basin and shape factor in the Dongkok watershed is larger than that in the Ieemokjung watershed. These conditions indicate that the Dongkok watershed has a more circular shape and a wider channel than the Ieemokjung watershed. In terms of the river density and basin slope, the Dongkok watershed is slightly larger than the Ieemokjung watershed.

Table 1. Topographic characteristics of the Dongkok and Ieemokjung watersheds.

\begin{tabular}{ccc}
\hline Characteristics & Dongkok Watershed & Ieemokjung Watershed \\
\hline Drainage area $\left(\mathrm{km}^{2}\right)$ & 33.63 & 55.76 \\
River length $(\mathrm{km})$ & 8.00 & 16.55 \\
Main tributary length $(\mathrm{km})$ & 39.92 & 53.25 \\
Mean width of basin $(\mathrm{km})$ & 4.203 & 3.370 \\
Shape factor & 0.525 & 0.204 \\
Drainage density $\left(\mathrm{km} / \mathrm{km}^{2}\right)$ & 1.188 & 0.955 \\
Basin slope & 0.452 & 0.344 \\
\hline
\end{tabular}

The applied DEM spatial resolution values were 5, 10, 20, 40, 80, 160, 200, and $300 \mathrm{~m}$, using ArcGIS. DEM data scales for Dongkok and Ieemokjung watersheds were 1:5000 and 1:25,000, respectively. The hydrological data were based on rainfall data, and the runoff data were obtained from the International Hydrological Programme (IHP) report [24]. The present study chose four rainfall-runoff events in the Dongkok watershed and seven events in the Ieemokjung watershed. The parameters of the selected rainfall-runoff events are listed in Table 2. Rainfall-runoff events in the 1990s were adopted because the applied DEM data and verified streamflow data for TOPMODEL for the target 
watersheds were created in the late 1990s by the National Geographic Information Institute in Korea (https://www.ngii.go.kr) [24,25].

Table 2. Selected rainfall-runoff events in the TOPMODEL application.

\begin{tabular}{|c|c|c|c|c|}
\hline Watershed & Year & $\begin{array}{c}\text { Rainfall-Runoff } \\
\text { Event Time (m.dd.hh) }\end{array}$ & $\begin{array}{l}\text { Durations of } \\
\text { Events (h) }\end{array}$ & Name of Events \\
\hline \multirow{4}{*}{ Dongkok } & \multirow{2}{*}{1996} & 6. 16. 23-6. 17. 22 & 16 & DK960616 \\
\hline & & 8. 26. 22-8. 27. 19 & 17 & DK960826 \\
\hline & 1997 & 7. 15. 18-7. 16. 21 & 17 & DK970715 \\
\hline & 1998 & 8. 15. 14-8. 17. 10 & 16 & DK980815 \\
\hline \multirow{7}{*}{ Ieemokjung } & 1991 & 5. 25. 13-5. 26. 17 & 26 & IM910525 \\
\hline & 1992 & 9. $24.6-9.24 .24$ & 17 & IM920924 \\
\hline & \multirow{2}{*}{1994} & 6. 29. 23-7. 1. 23 & 42 & IM940629 \\
\hline & & 8. 1. 3-8. 2. 4 & 19 & IM940801 \\
\hline & \multirow{2}{*}{1996} & 7. 4. 13-7. 5. 5 & 13 & IM960704 \\
\hline & & 8. 25. 13-8. 27. 24 & 17 & IM960825 \\
\hline & 1999 & 7. 28. 3-7. 29. 24 & 42 & IM990728 \\
\hline
\end{tabular}

\section{Materials and Methods}

\subsection{TOPMODEL}

TOPMODEL simulates the runoffs using the water balance due to precipitation, estimated infiltration (regarded as a saturation deficit), and the loss by evapotranspiration. Figure 2 shows the basic concept of the TOPMODEL scheme. $P$ represents the precipitation, $a_{i}$ is the slope area per unit contour length, $q_{i}$ is the runoff per unit width, $S_{r z}$ is the root-zone deficit, and $S_{u z}$ is the local water storage in the unsaturated zone. $q_{v}$ is the flux of water that locally enters the water table (per unit area), and $Q$ represents the drainage of the watershed unit. The formula that serves as the basis of TOPMODEL is based on the continuity equation and Darcy's Law. The model equation is developed through several important assumptions as follows.

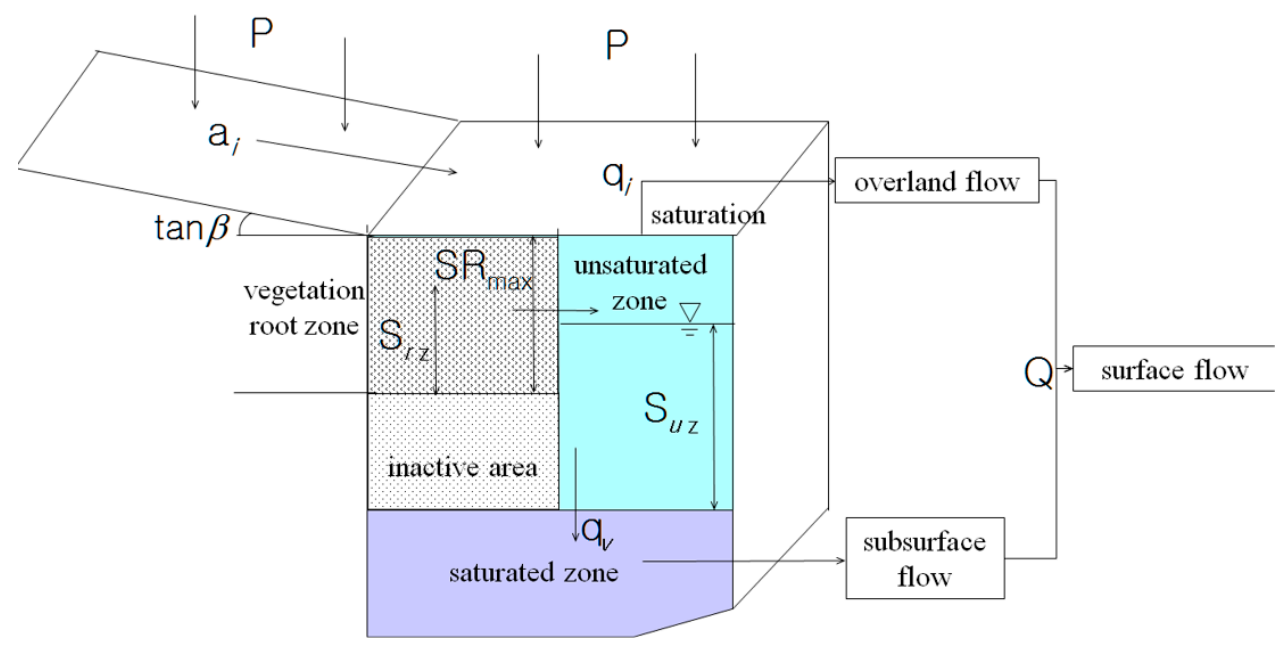

Figure 2. Basic concept of the TOPMODEL scheme (modified from $[5,14,19])$.

First, the flow of water in the watershed is assumed to be at a steady state.

Second, the hydraulic gradient of the saturated soil in the watershed can be expressed as $\tan \beta$, which represents the surface gradient. 
Third, the saturation permeability coefficient $\left(T_{0}, \mathrm{~m}^{2} / \mathrm{h}\right)$ exponentially decreases from the soil surface to the groundwater surface. These assumptions indicated that the most important factor on the storage and groundwater of the watershed is the topographic index, also known as topographic wetness index, i.e., $\left(\ln \left(\frac{a}{\tan \beta}\right)\right)[26-30]$.

The saturated hydraulic conductivity of soil $\left(K_{s}, \mathrm{~m} / \mathrm{h}\right)$ can be expressed as a negative exponential function with respect to depth, as follows:

$$
K_{\mathrm{s}}=K_{0} \exp (-f z)
$$

where $z(\mathrm{~m})$ is the underground water depth, $K_{0}(\mathrm{~m} / \mathrm{h})$ is the coefficient of permeability of the soil at the ground surface, and $f(1 / \mathrm{m})$ is the coefficient ratio of the $K_{s}$ change depending on underground water depth $z$. $f$ was assumed to be constant in the entire watershed.

The hydraulic gradient in the saturated layer can be expressed as a topographic slope in the watershed, and the behavior of the saturated layer follows Darcy's Law. Therefore, the flow rate per unit width $q_{i}\left(\mathrm{~m}^{2} / \mathrm{h}\right)$ at point $i$ is expressed as follows:

$$
q_{i}=T_{i}\left(z_{i}\right) \tan \beta_{i}
$$

where $\tan \beta_{i}$ is the slope of the surface at location $i$, and $T_{i}\left(z_{i}\right)$ is the transmissivity coefficient. $T_{i}\left(z_{i}\right)$ in Equation (2) can be obtained by integrating Equation (1) as follows:

$$
T_{i}\left(z_{i}\right)=\int_{z_{i}}^{z(t)} K_{s}(x) d x=\frac{K_{0}}{f}\left[\exp \left(-f z_{i}\right)-\exp (-f z)\right]=\frac{1}{f}\left[K_{s}\left(z_{i}\right)-K_{s}(z)\right]
$$

Generally, when depth $z$ of the groundwater is large, the saturation permeability coefficient $K_{s}(z)$ $(\mathrm{m} / \mathrm{h})$ is negligible, because it is very small compared with saturation permeability $K_{s}\left(z_{i}\right)$ at depth $z_{i}$. Therefore, substituting Equation (3) into Equation (2) yields the following equation:

$$
q_{i}=\frac{K_{0}}{f} \tan \beta_{i} \exp \left(-f z_{i}\right)=T_{0} \tan \beta_{i} \exp \left(-f z_{i}\right)
$$

where $T_{0}=K_{0} / f$ is the coefficient of permeability of the fully saturated soil. $K_{0}$ and $f$ were assumed to be constant in the entire watershed.

In addition, the behavior of the flow in the saturation layer can be expressed as a continuous steady state as follows:

$$
q_{i}=a_{i} R=T_{0} \tan \beta_{i} \exp \left(-f z_{i}\right)
$$

where $R(\mathrm{~m} / \mathrm{h})$ is the spatially constant recharge of the groundwater at any given time, and $a_{i}(\mathrm{~m})$ is the area of the slope per unit contour length drained through point $i$.

Equation (5) can be summarized based on $z_{i}$, and the average value $(\bar{z})$ of the entire watershed can be obtained as follows:

$$
z_{i}=-\frac{1}{f}\left(\ln \frac{R a_{i}}{T_{0} \tan \beta_{i}}\right)
$$

where $R$ is spatially constant, and $\ln \left(\frac{a}{T_{0} \tan \beta}\right)$ is the soil topographic index.

Introducing average topographic indexes to Equation (6) yields the following equation:

$$
z_{i}=\bar{z}-\frac{1}{f}\left[\ln \frac{a_{i}}{T_{0} \tan \beta_{i}}-E\left(\ln \frac{a_{i}}{T_{0} \tan \beta_{i}}\right)\right]
$$

where $E($ ) denotes the average topographic indexes of the entire watershed [31].

Equation (7) demonstrates that depth $z_{i}$ of the groundwater can be determined by factor $\mathrm{f}$ and topographic index $\left(\ln \left(\frac{a}{\tan \beta}\right)\right)$. 
Thus, given the value of $\bar{z}$, Equation (7) can be used to estimate the spatial distribution of the topographic indexes and to predict the behavior of the surface water and groundwater levels in the entire watershed, assuming that the topographic index is spatially constant [11]. The soil topographical factors and topographic constants represent the behavior of all the flows in the watershed. All points with the same soil topographic factors and topographic constants exhibit the same flow performance. Therefore, the soil topographical factors and topographic constants could indicate the hydrological similarities between the watersheds.

The input data of TOPMODEL were divided into hydrological data, topographic data, and input parameters. The hydrological data comprised the rainfall, evapotranspiration, and observed flow data. The topographic data were obtained by extracting the DEM data from a digital map. This study applied the FORTRAN source code of TOPMODEL [1]. Figure 3 shows the calculation procedure of TOPMODEL. TOPMODEL calculated the input data, compared the calculated value with the actual value, and reduced the error generated by parameter optimization.

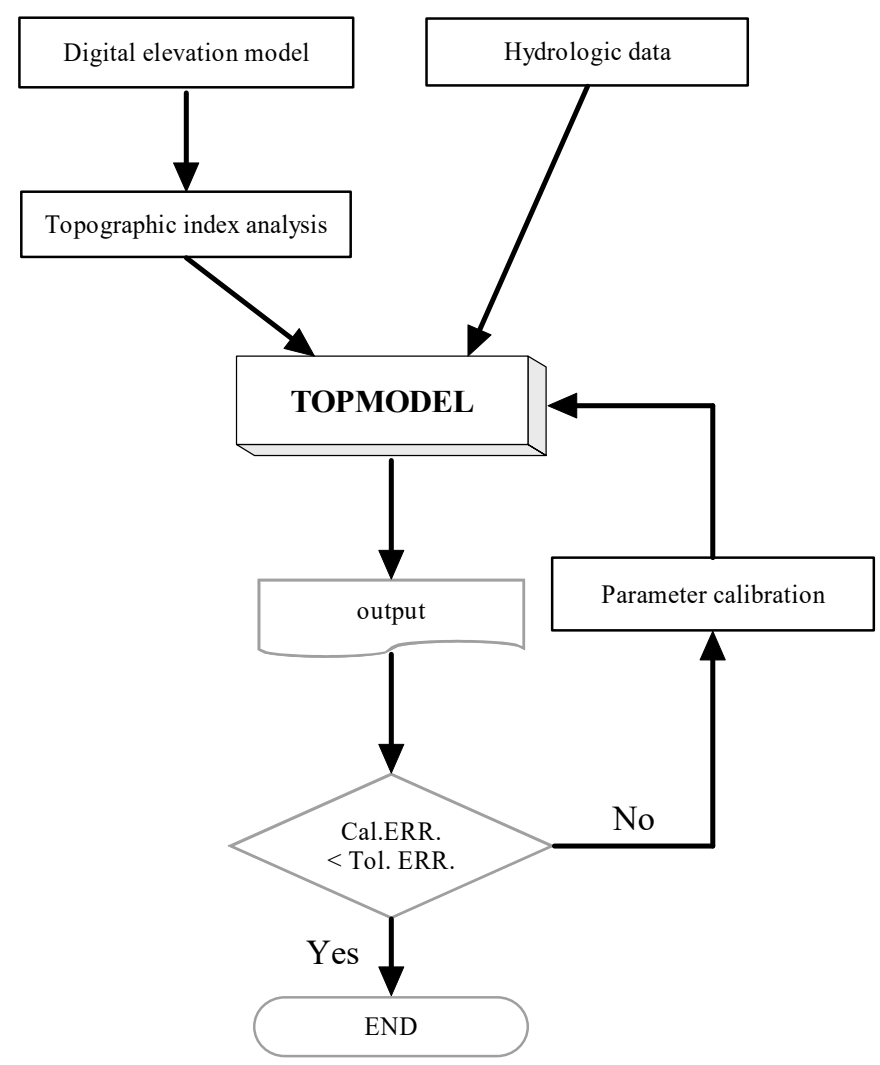

Figure 3. Flowchart of the TOPMODEL simulation. TOPMODEL: TOPography-based hydrological MODEL.

\subsection{Input Parameters Optimization}

TOPMODEL is a model that analyzes the runoff characteristics in a watershed by simulating the behavior of groundwater in the soil using the soil topographical factors of the watershed. The topographic parameters are the main parameters that determine the response characteristics in the subwatershed or slope, including the topographic index factors. TOPMODEL contains five calibration parameters such as the exponential storage parameter $(m)$, log-transformed soil-water permeability coefficient $\left(\ln \left(T_{0}\right)\right)$, unsaturated lag time $\left(T_{d}\right)$, maximum vegetation storage $\left(S R_{\max }\right)$, and vegetation deficiency $\left(S R_{0}\right)$, as listed in Table 3. Each input parameter in TOPMODEL is constant to all DEM grid cell sizes as one parameter set. In other words, each input parameter is changed as the grid cell size or applied Rainfall-runoff events are changed, but is not changed by DEM grid cell numbers. These parameters are characterized as nominal values. The input parameters were estimated using 
all possible combinations of calibration ranges in Table 3 to compare the observed flows with the calculated flows. Calibration ranges of all input parameters were based on Cho [32] and Lee [33]. This study optimized the input parameters for all five parameter combinations with different segments (e.g., 0.001 for $m$ and 0.1 for $S R_{\max }, 0.01$ for $S R_{0}$, and 1 for $\ln \left(T_{0}\right)$ and $T_{d}$ ), depending on grid cell size change and Rainfall-runoff events in Fortran. The objective function of optimization parameters in this study adopted the Nash-Sutcliffe efficiency (NSE) [34]. This study selected input parameter values that maximized the NSE estimations between the actual and simulated runoffs using the actual rainfall and runoff data from the Dongkok and Ieemokjung watersheds.

Table 3. Calibration parameters and ranges used in TOPMODEL in this study $[32,33]$.

\begin{tabular}{cccc}
\hline Parameters & Description & Units & Calibration Range \\
\hline$m$ & Exponential storage parameter & $\mathrm{m}$ & $0.001-0.1$ \\
$\ln \left(T_{0}\right)$ & Soil-water permeability coefficient & $\ln \left(\mathrm{m}^{2} / \mathrm{h}\right)$ & $1-50$ \\
$T_{d}$ & residence time in unsaturated zone & $\mathrm{h}$ & $1-50$ \\
$S R_{\max }$ & Maximum vegetation storage & $\mathrm{m}$ & $0.1-1$ \\
$S R_{0}$ & Vegetation deficiency & $\mathrm{m}$ & $0.01-1$ \\
\hline
\end{tabular}

\section{Results}

This study investigated the results of the topographic characteristics of the experimental watersheds, DEM size effects based on fixed parameter sets, and DEM size sensitivity based on various parameter sets. According to these results, the least sensitive resolution of the DEM grid cell size for TOPMODEL in the Dongkok and Ieemokjung watersheds was analyzed.

\subsection{Frequencies of the Topographic Indexes Based on the DEM Grid Cell Size}

Figures 4 and 5 show the frequency and cumulative frequency of the topographical indexes based on the grid cell size of the Dongkok and Ieemokjung watersheds, respectively. The curves in Figures 4 and 5 shifted from left to right as the grid cell size increased for both the Dongkok and Ieemokjung watersheds. These results indicate that the mean of topographic index $\left(\ln \left(\frac{a}{\tan \beta}\right)\right)$ increases as DEM cell resolution is coarser. It is because contributing area (a) increases, and the slope of watershed $(\tan \beta)$ decreases as DEM cell size increases. This analysis is coincided with Figure 6, which shows the $\log$-transformed contributing area $(\ln (a))$ and the log-transformed inverse slope of watershed $\left(\ln \left(\frac{1}{\tan \beta}\right)\right)$ increase as DEM cell resolution is coarser [13,35].

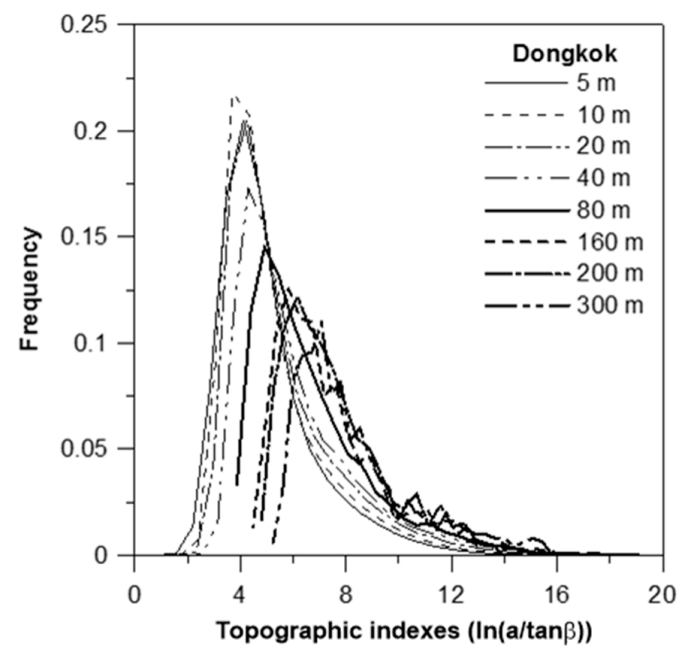

(a)

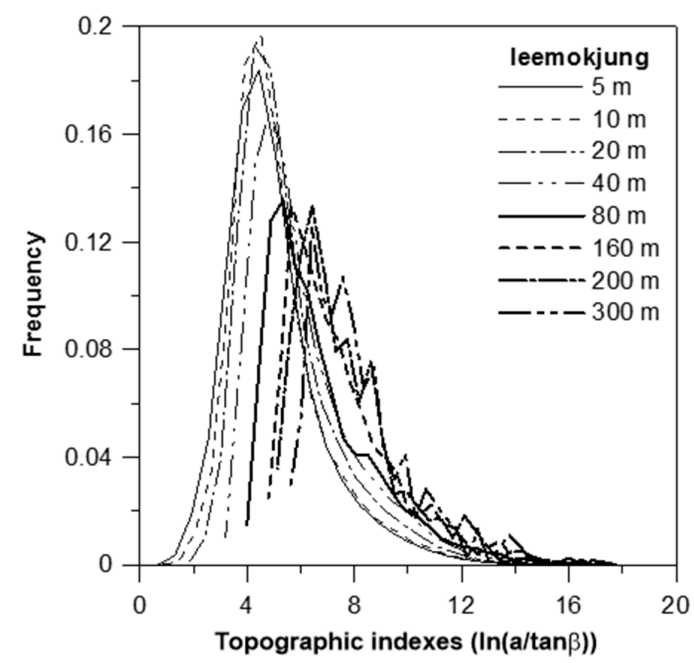

(b)

Figure 4. Frequency distribution of the topographic indexes $\left(\ln \left(\frac{a}{\tan \beta}\right)\right)$ based on the DEM grid cell size. (a) Dongkok watershed. (b) Ieemokjung watershed. 


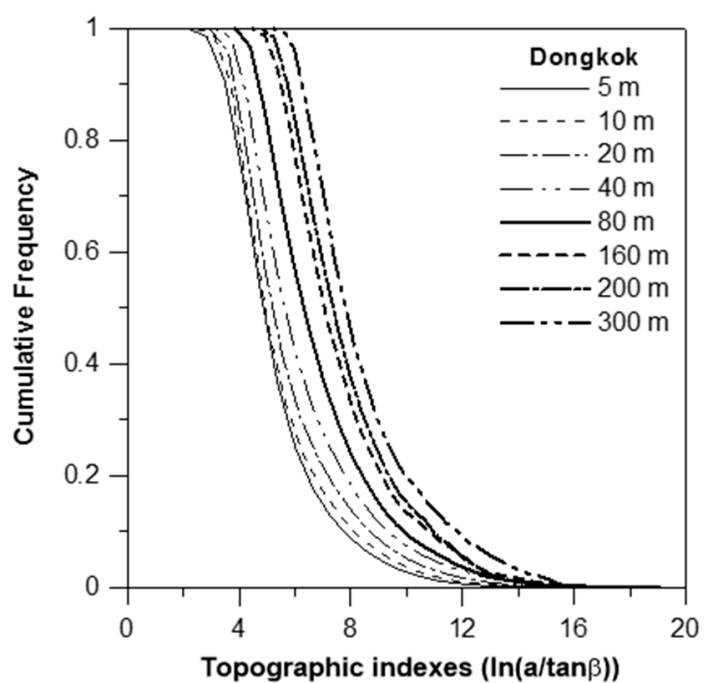

(a)

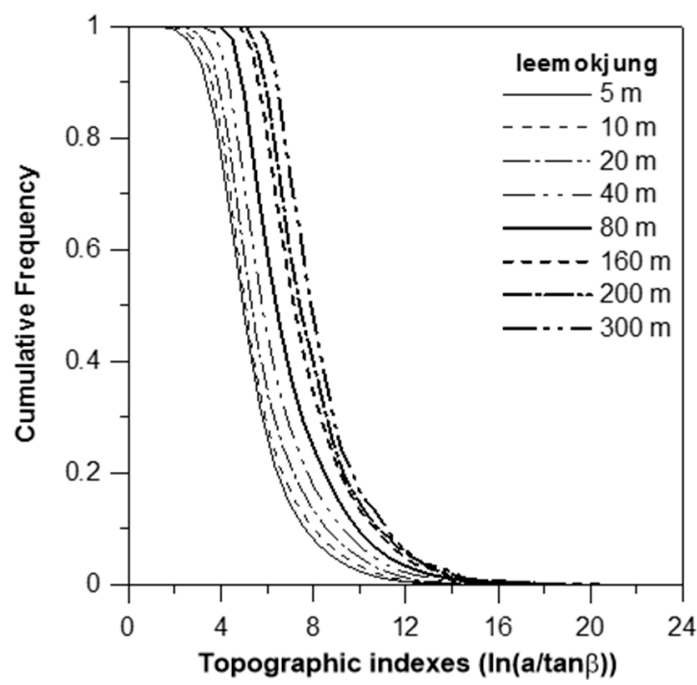

(b)

Figure 5. Cumulative frequency of the topographic indexes $\left(\ln \left(\frac{a}{\tan \beta}\right)\right)$ based on the DEM grid cell size. (a) Dongkok watershed. (b) Ieemokjung watershed.

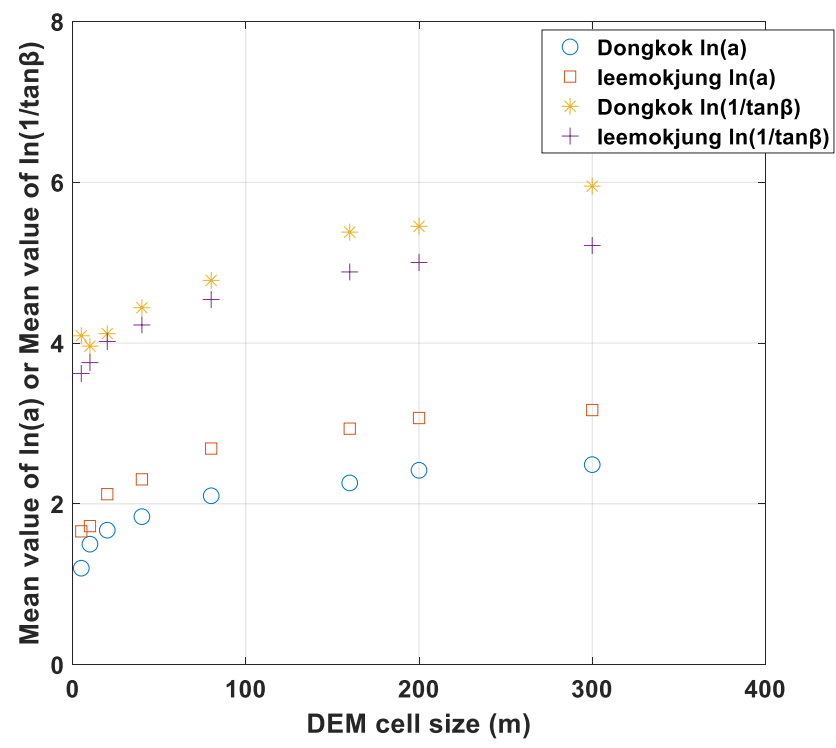

Figure 6. Relation of mean topographic indexes $\left(\ln \left(\frac{a}{\tan \beta}\right)\right)$ to mean $\ln (\mathrm{a})$ and mean $\ln (1 / \tan \beta)$ values based on DEM cell size in Dongkok and Ieemokjung watersheds.

Figure 7 shows the variation in the contributing area of the grid cell size in the Dongkok and Ieemokjung watersheds, which depended on the Rainfall-runoff events. Figure 7a shows that the contributing area increased with respect to the grid cell size, but the slopes of the curves in the grid cell size in the Dongkok watershed were different depending on the Rainfall-runoff events. The slopes (ratio) of the curves in DK960826 and DK980815 were 0.239 and 0.337, respectively, and those in DK960616 and DK970715 were 0.609 and 0.803, respectively. The variation range in the slopes was between 0.239 and 0.803 . Figure $7 \mathrm{~b}$ shows the change in the slope of the curves in the grid cell size from 0.356 to 0.540 in the Rainfall-runoff events in the Ieemokjung watershed. Figure 7 shows that the contributing area in the Rainfall-runoff events and grid cell size varied. In other words, when the grid cell size was large, the contributing area increased, but the contributing area varied depending on the characteristics of the Rainfall-runoff events, even when the grid cell size was constant. The change of contributing area depending on rainfall events in Figure 6 shows a good agreement that the contributing area is not stationary but changes over both storm and seasonal timescales, reflecting 
changes in the average watershed water balance, topography, and soil conditions. Particularly, the contributing area differs from the mean watershed deficit related to the watershed water balance for the saturated zone $[1,36,37]$. It implies that rainfall events affect mean watershed deficit, and different mean watershed deficits influence the contributing area. Also, several studies found that the influence of DEM resolution was through its effect on the calculation of the contributing area $[13,35]$. However, more results and studies need to be provided to clarify the relation among rainfall events, contributing area, input parameters, and DEM resolution.

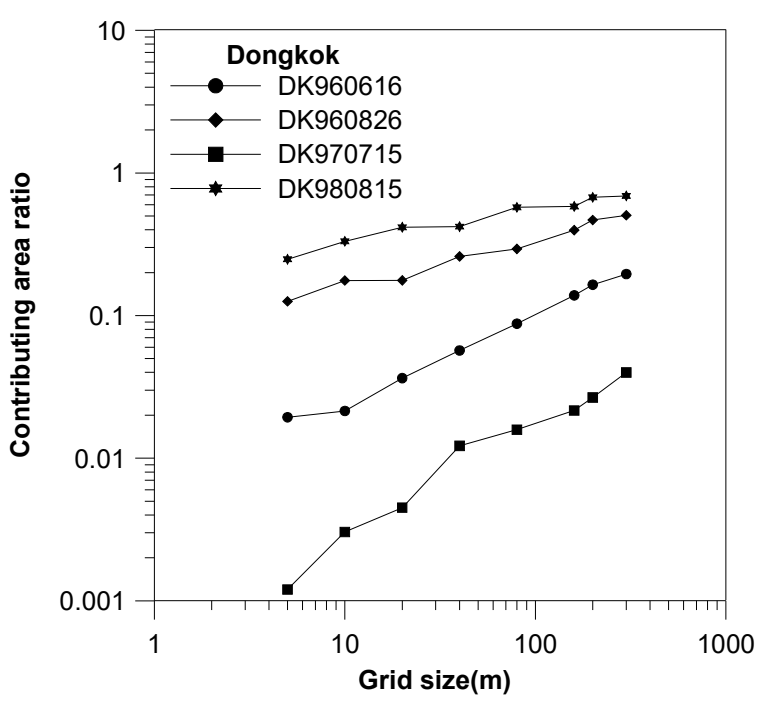

(a)

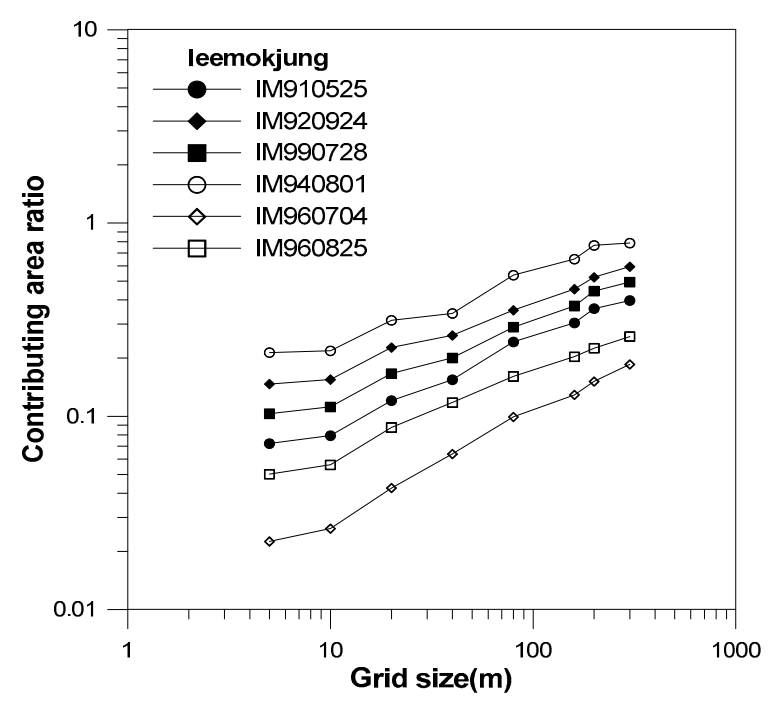

(b)

Figure 7. Change in the ratio of the contributing area based on the DEM grid cell size. (a) Dongkok watershed. (b) Ieemokjung watershed.

\subsection{Resolution Effects of the Grid Cell Size with Fixed Parameter Sets}

Figure 8 shows the hydrographs in the Dongkok watershed, which varied depending on the grid cell size with fixed input parameter sets. Fixed parameter sets were used to investigate the resolution effects of the grid cell size. This study chose a fixed parameter set that displayed the best fit in a $5 \mathrm{~m}$ grid cell size based on the Rainfall-runoff events in Table 4. Figure 8 shows that the estimated hydrographs with a smaller grid cell size were closer to the observed hydrograph. In contrast, when the grid cell size was larger, the simulated hydrograph was larger than the observed one because the grid cell size and contributing area were larger. The larger contributing area resulted in more runoffs. In particular, Figure $8 \mathrm{~b}$,d show that the peak rainfall matched with the estimated peak hydrographs under different grid cell sizes, which indicated that the larger the grid cell size, the larger the contributing area and the more sensitive the runoff to peak rainfall. Figure 9 shows the hydrographs whose DEM grid size varied with the application of fixed parameter sets in each hydrological event in the Ieemokjung watershed. Similarly, the input parameter set used the best fitting parameter set for the 5-m grid size in Table 5. Similar to the Dongkok watershed, the estimated runoffs well matched with the observed hydrographs because the DEM grid size was smaller in the Ieemokjung watershed. In Figures 8 and 9, the hydrographs for coarser DEM resolution provided greater surface runoffs. It is because the depth $z_{i}$ of the groundwater decreases as the topographic index increases, from Equation (6) [16,35]. Particularly, negative $z_{i}$ means the unsaturated zone in the DEM grid is saturated. Decreasing depth of the groundwater leads to decreasing infiltration rate and increasing surface runoff in the constant rainfall condition. In other words, the infiltration rate decreases as a topographic index increases or the DEM grid cell resolution is coarser [38,39]. 


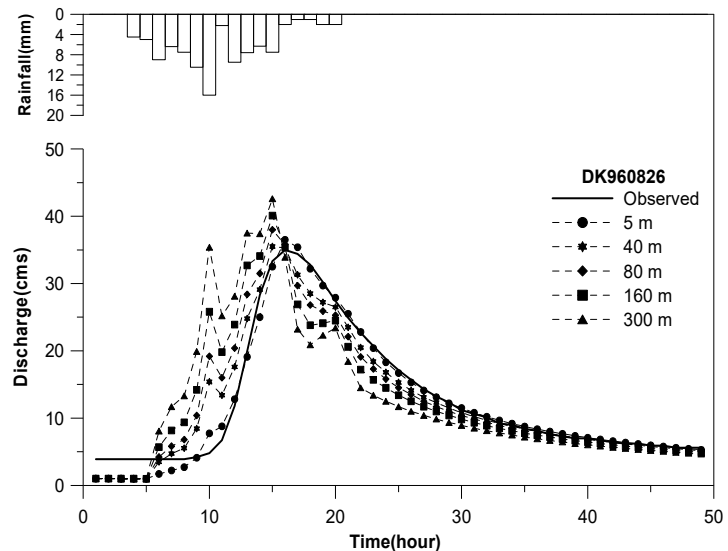

(a)

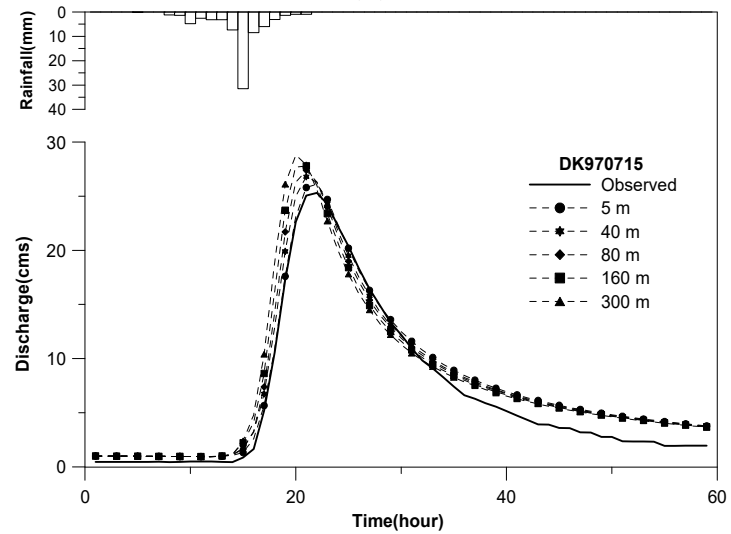

(c)

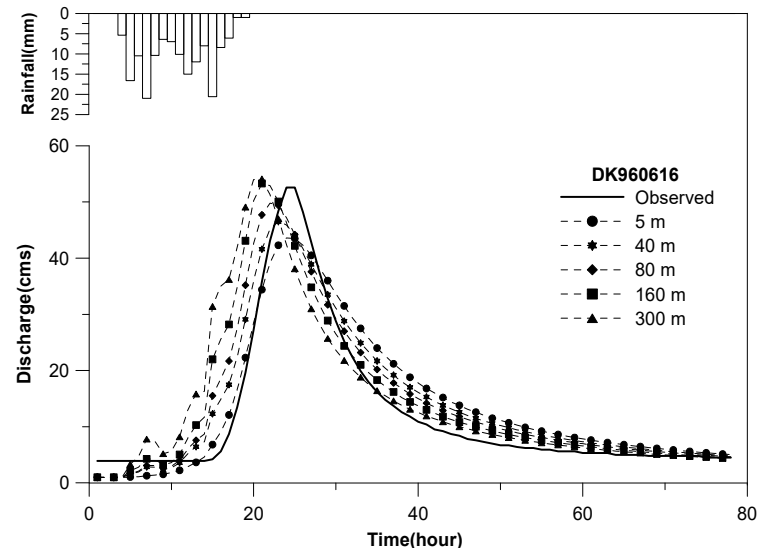

(b)

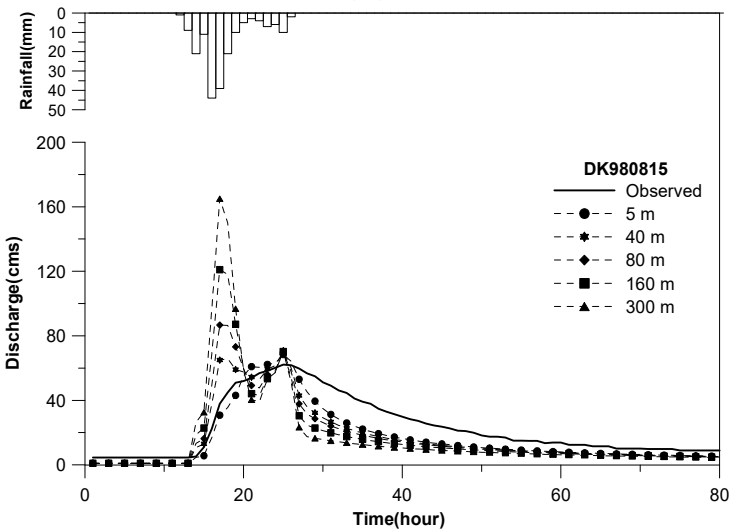

(d)

Figure 8. Rainfall-runoff events by applying a constant parameter set depending on different DEM resolution values in the Dongkok watershed. (a) 16 June 1996. (b) 26 August 1996. (c) 26 July 1997. (d) 15 August 1998.

Table 4. Applied fixed input parameter sets in the Dongkok watershed.

\begin{tabular}{cccccc}
\hline Hydrologic & \multicolumn{5}{c}{ Input Parameters } \\
\cline { 2 - 6 } Events & $\boldsymbol{m}$ & $\boldsymbol{I n}\left(\boldsymbol{T}_{0}\right)$ & $\boldsymbol{T}_{\boldsymbol{d}}$ & $\boldsymbol{S R}_{\max }$ & $\boldsymbol{S R}_{0}$ \\
\hline DK960616 & 0.025 & 5.0 & 49.0 & 0.1 & 0.01 \\
DK960826 & 0.019 & 2.0 & 17.0 & 0.1 & 0.01 \\
DK970715 & 0.016 & 8.0 & 15.0 & 0.1 & 0.01 \\
DK980815 & 0.032 & 1.0 & 14.0 & 0.1 & 0.01 \\
\hline
\end{tabular}

Table 5. Applied fixed input parameter sets in the Ieemokjung watershed.

\begin{tabular}{cccccc}
\hline Hydrologic & \multicolumn{5}{c}{ Input Parameters } \\
\cline { 2 - 6 } Events & $\boldsymbol{m}$ & $\boldsymbol{I n}\left(\boldsymbol{T}_{0}\right)$ & $\boldsymbol{T}_{\boldsymbol{d}}$ & $\boldsymbol{S R}_{\max }$ & $\boldsymbol{S R}_{0}$ \\
\hline IM910525 & 0.024 & 3.0 & 6.0 & 0.1 & 0.01 \\
IM920924 & 0.027 & 1.0 & 1.0 & 0.1 & 0.01 \\
IM940801 & 0.028 & 1.0 & 14.0 & 0.1 & 0.01 \\
IM960704 & 0.016 & 3.0 & 23.0 & 1.0 & 0.01 \\
IM960825 & 0.047 & 1.0 & 10.0 & 1.0 & 0.01 \\
IM990728 & 0.016 & 3.0 & 40.0 & 1.0 & 0.01 \\
\hline
\end{tabular}




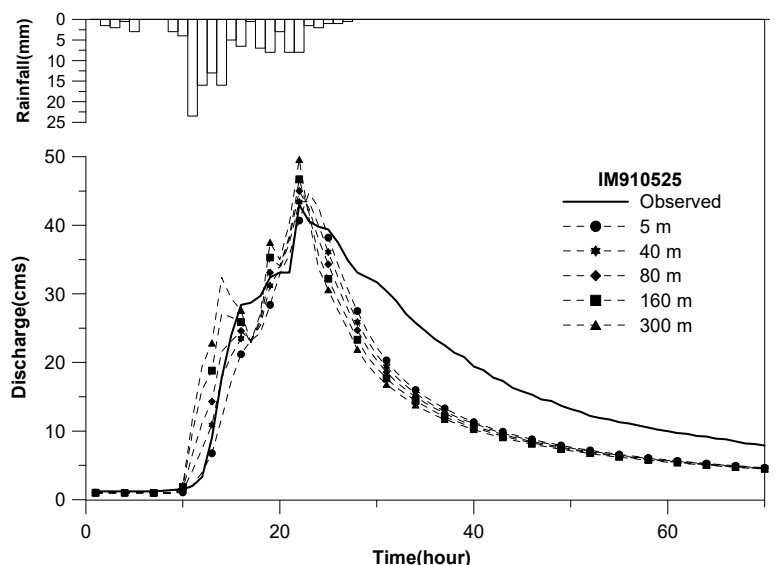

(a)

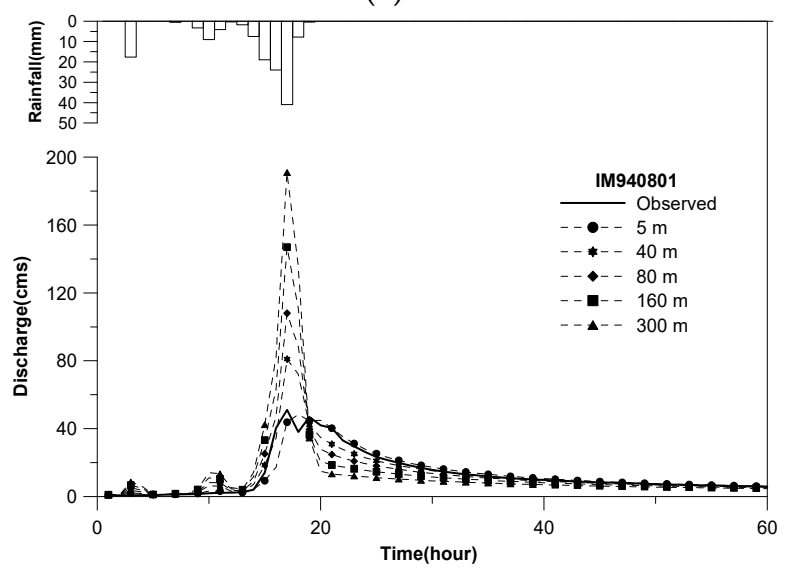

(c)

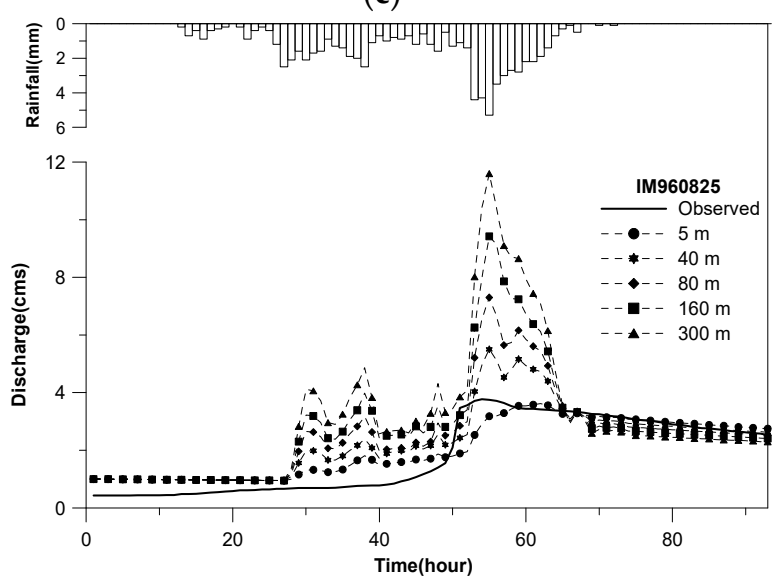

(e)

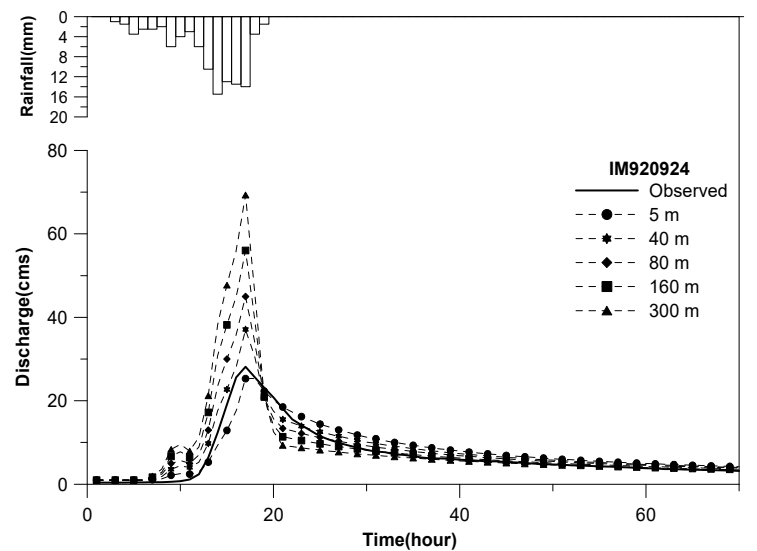

(b)

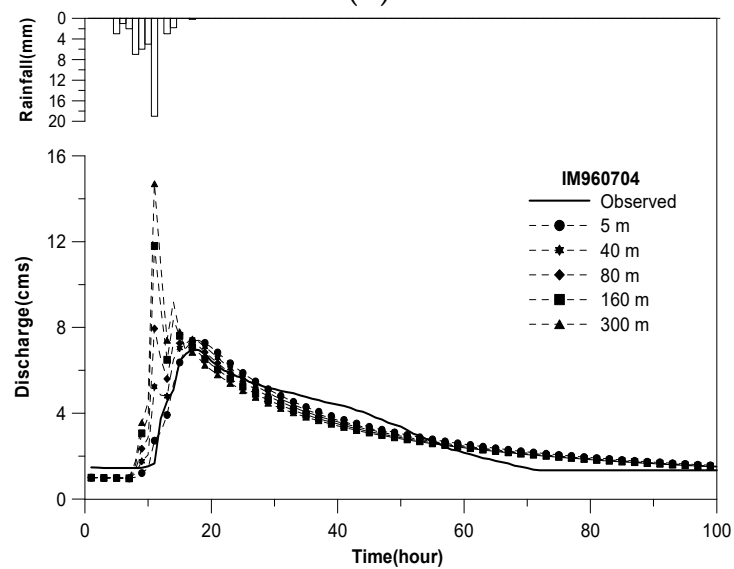

(d)

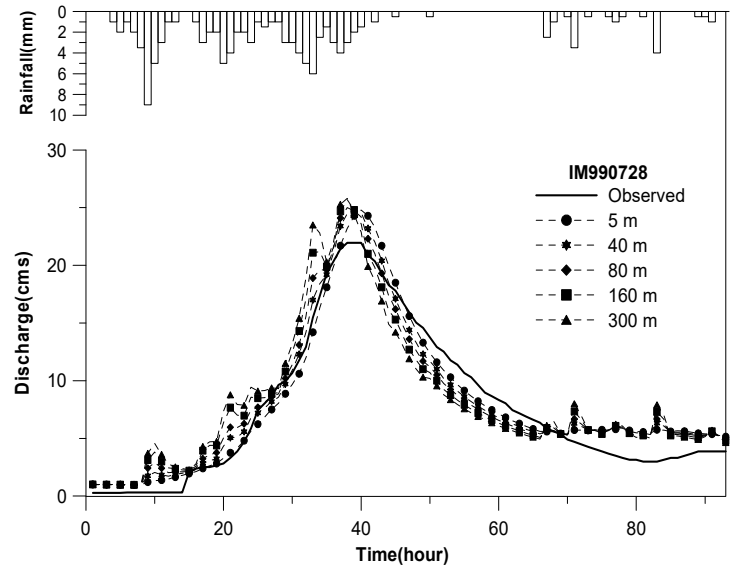

(f)

Figure 9. Rainfall-runoff events by applying a constant parameter set depending on different DEM resolution values in the Ieemokjung watershed. (a) 25 May 1991. (b) 24 September 1992. (c) 1 August 1994. (d) 4 July 1996. (e) 25 August 1996. (f) 25 July 1999.

\subsection{Parameter Optimization for Each DEM Grid Cell Size}

This study optimized input parameters of TOPMODEL depending on DEM resolutions and hydrologic events in the Dongkok and leemokjung watersheds in Figures 10 and 11. The input parameters are optimized based on the changes of DEM grid cell size and rainfall-runoff events. When the grid cell size changes, the simulated runoff shows a large change with parameter $m$, a small change with parameters $\ln \left(T_{0}\right)$ and $T_{d}$, and no change with $S R_{\max }$ and $S R_{0}$. Parameter $m$ is the most sensitive because it is a parameter in an exponential equation, and the results in Figures 10 and 11 change 
significantly with changes in this parameter. The parameters $\ln \left(T_{0}\right)$ and $T_{d}$ increase as DEM grid size is greater. It demonstrates that an ultimate infiltration capacity, the soil-water permeability coefficient $\left(\ln \left(T_{0}\right)\right)$ in this study, decreases as DEM grid cell resolution is coarser $[38,39]$. Therefore, it is necessary to increase the parameter $\ln \left(T_{0}\right)$ as well as the lag time in the unsaturated zone $\left(T_{d}\right)$ to increase the actual infiltration capacity rate as DEM grid cell resolution decreases.

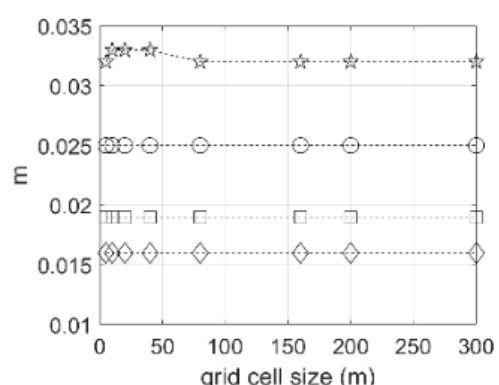

(a)

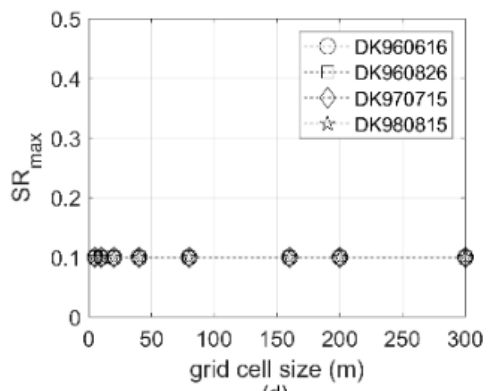

(d)

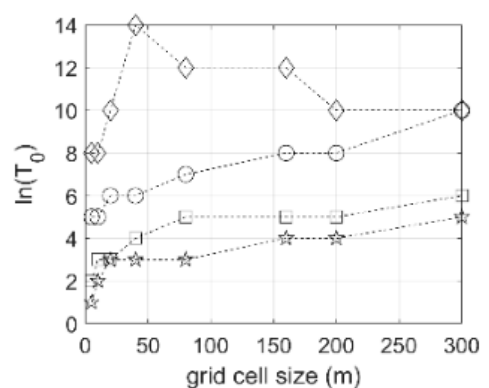

(b)

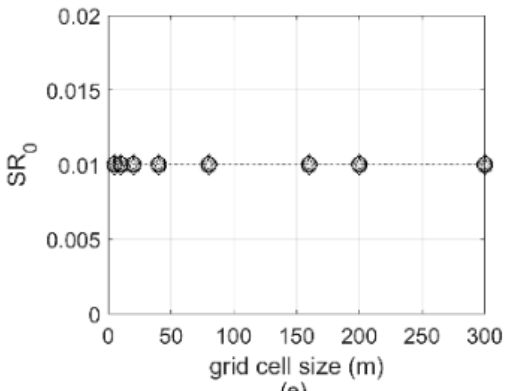

(e)

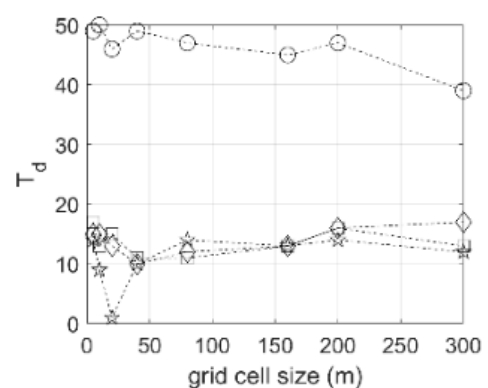

(c)

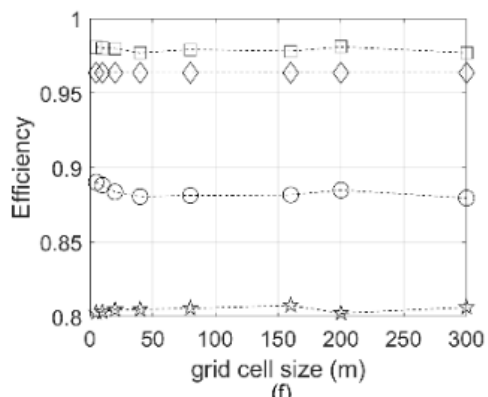

(f)

Figure 10. Optimized parameters depending on DEM resolutions in each hydrologic event, the Dongkok watershed. (a) exponential storage parameter $(\mathrm{m}),(\mathbf{b})$ soil-water permeability coefficient $\left(\ln \left(T_{0}\right)\right)$, (c) unsaturated lag time $\left(T_{d}\right),(\mathbf{d})$ maximum vegetation storage $\left(S R_{\max }\right),(\mathbf{e})$ Vegetation deficiency $\left(S R_{0}\right)$, (f) model efficiency.

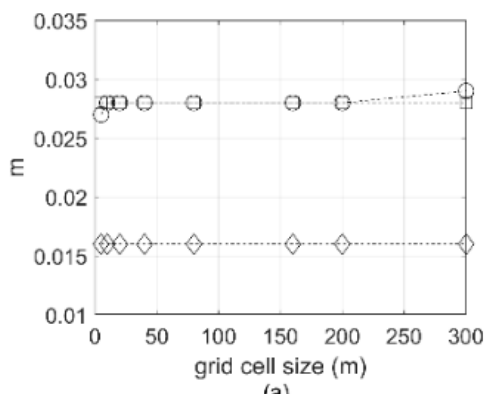

(a)

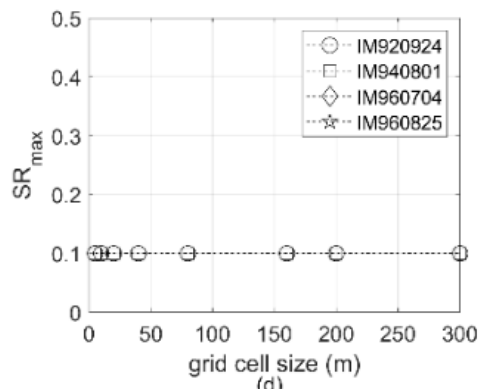

(d)

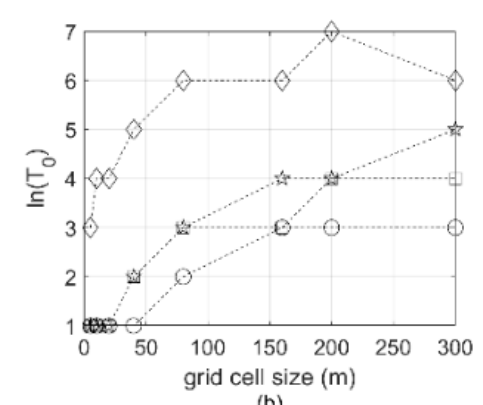

(b)

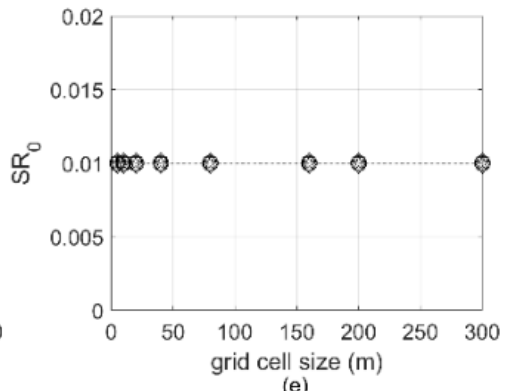

(e)

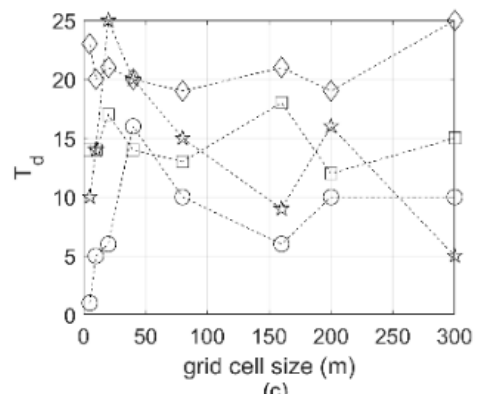

(c)

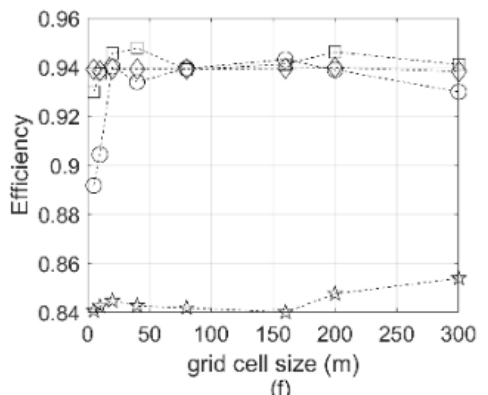

(f)

Figure 11. Optimized parameters depending on DEM resolutions in each hydrologic event, the Ieemokjung watershed. (a) exponential storage parameter $(\mathrm{m}),(\mathbf{b})$ soil-water permeability coefficient $\left(\ln \left(T_{0}\right)\right),(\mathbf{c})$ unsaturated lag time $\left(T_{d}\right),(\mathbf{d})$ maximum vegetation storage $\left(S R_{\max }\right),(\mathbf{e})$ Vegetation deficiency $\left(S R_{0}\right)$, (f) model efficiency. 
Figures 12 and 13 show TOPMODEL hydrographs based on the optimization of the input parameters in the Dongkok and leemokjung watersheds depending on the DEM resolution. The NSEs of the Dongkok watershed shown in Figures 10 and 12a ranged from 0.88 to $0.90,0.97$ to $0.98,0.94$ to 0.96, and 0.77 to 0.80 depending on the events. In particular, in the DK960616 and DK970715 events in Figure 10, the generated peak flows were very close to observed peak flows depending on the resolution of the DEM grid cell size. Therefore, the result indicated that the TOPMODEL efficiencies were slightly different based on the DEM grid cell size resolution; however, the optimized input parameters were significantly different based on the hydrological events. The NSE of the Ieemokjung watershed shown in Figures 11 and $12 \mathrm{~b}$ ranged from 0.89 to $0.94,0.88$ to $0.94,0.88$ to 0.93 , and 0.8 to 0.86. In the IM960704 and IM960825 events, the estimated peak flow rates were very close to observed peak flows depending on the DEM resolution. In addition, similar to the Dongkok watershed, the NSE efficiencies significantly varied depending on the rainfall-runoff events instead of the DEM resolution.

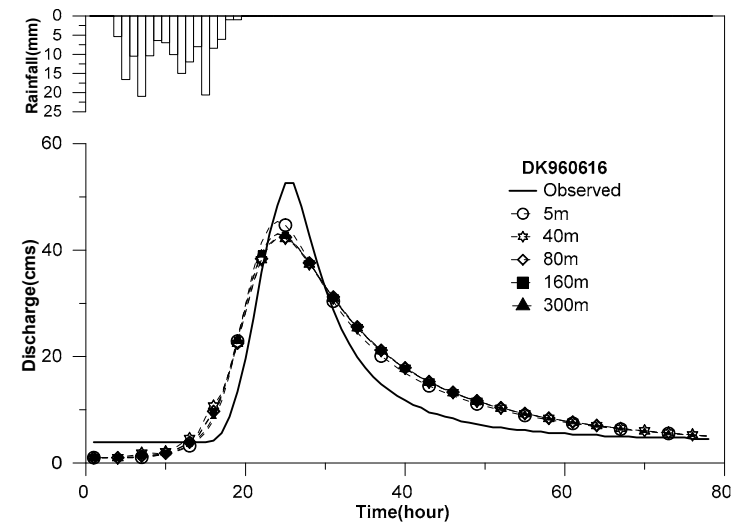

(a)

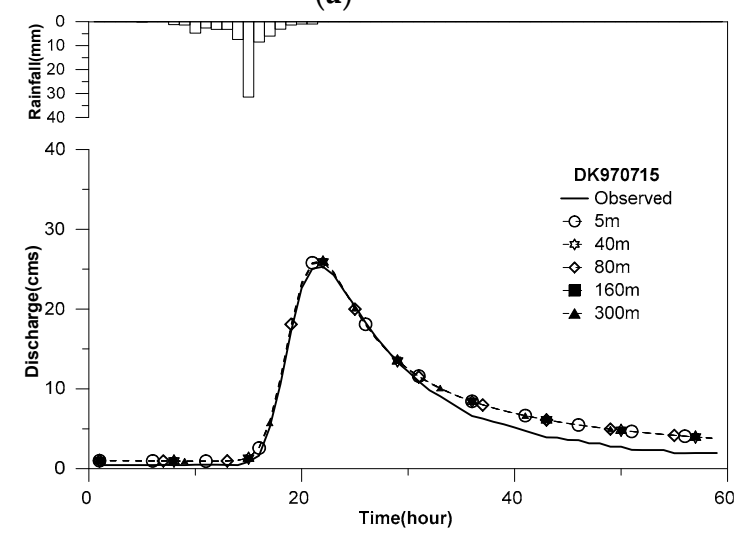

(c)

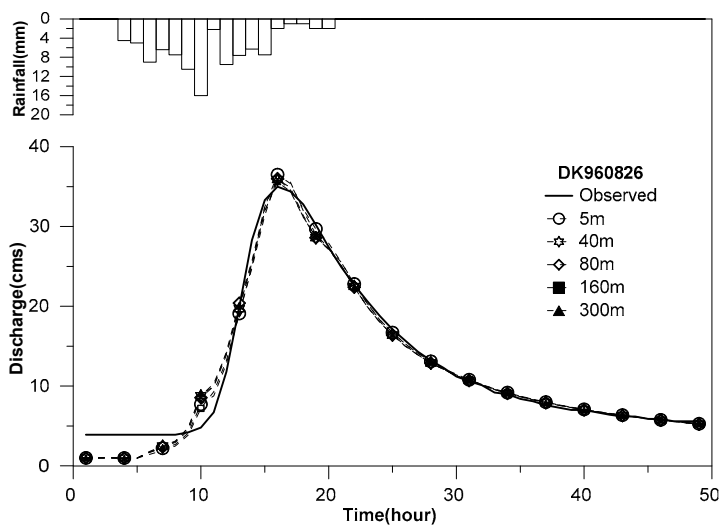

(b)

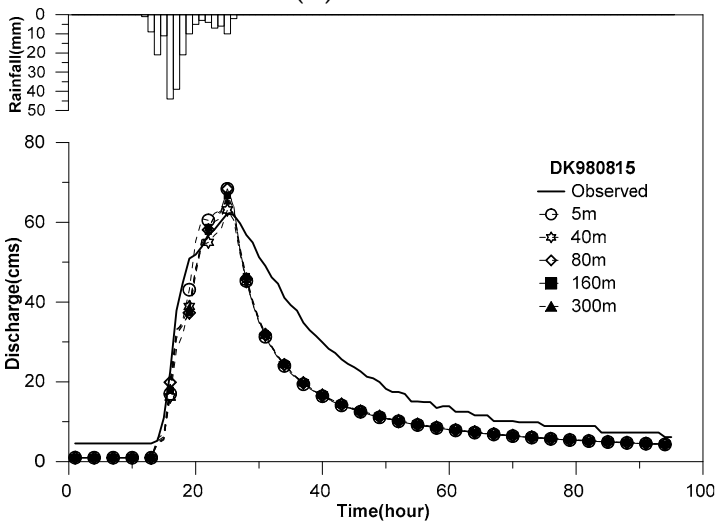

(d)

Figure 12. Rainfall-runoff events by applying optimized parameters in the Dongkok watershed depending on each DEM resolution. (a) 16 June 1996. (b) 8 August 1996. (c) 15 July 1997. (d) 15 August 1998. 


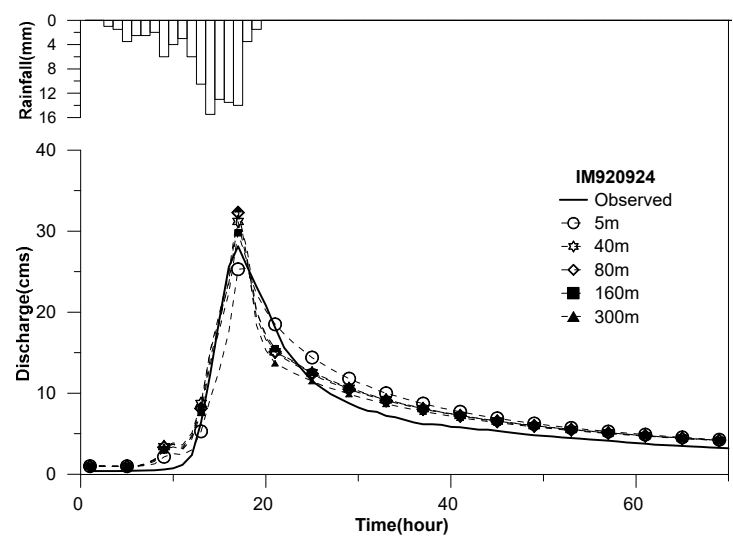

(a)

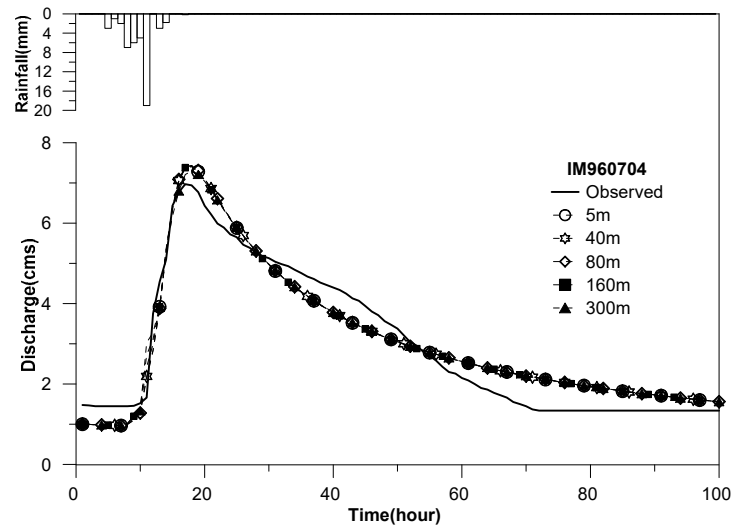

(c)

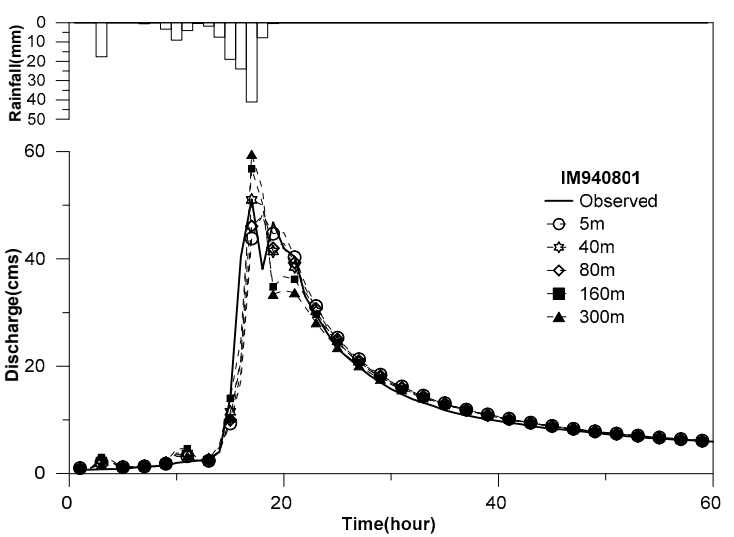

(b)

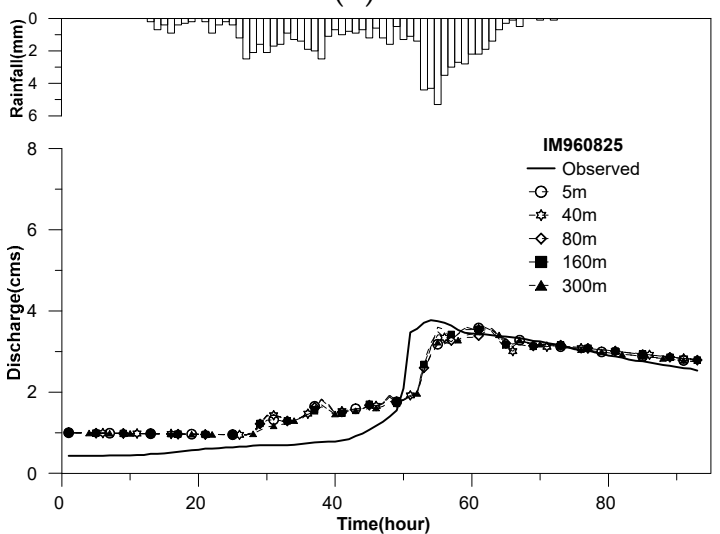

(d)

Figure 13. Rainfall-runoff events by applying optimized parameters in the Ieemokjung watershed depending on each DEM resolution. (a) 24 September 1992. (b) 1 August 1994. (c) 4 July 1996. (d) 25 August 1996.

\section{Discussion}

Because the watershed in the distributed watershed models was divided into multiple grid networks, the topography and Rainfall-runoff characteristics of the watershed varied depending on the DEM grid cell size. If the resolution of the DEM grid cell size is very high, it can accurately represent the characteristics of actual Rainfall-runoff events in a watershed. However, the simulation time for the runoff estimation and topography analysis in the model increase. If the resolution of the DEM grid cell size is too low, the geographical characteristics of the actual watershed are very simple, and a risk of computational errors exists [35]. Therefore, the present study proposed optimum DEM resolution on the basis of the work efficiency and runoff output accuracy in the Dongkok and Ieemokjung watersheds.

Figure 14 shows the NSE box plots in the Dongkok and Ieemokjung watersheds when the parameters were optimized in each grid for all Rainfall-runoff events. TOPMODEL hydrographs obtained using the optimized parameters in each DEM resolution were similar to the observed runoff data, which indicated that the resolution did not affect the model because the input parameters were well optimized depending on the DEM resolution.

Figure 15a shows the efficiency under a constant parameter set in the Dongkok watershed when the resolution was varied. The efficiencies of the 5 and $40 \mathrm{~m}$ DEM resolution slightly changed, but the efficiencies of the $80 \mathrm{~m}$ or higher DEM resolution significantly changed with the constant parameter set. Similarly, Figure 15b shows the efficiency under a constant parameter set in the Ieemokjung watershed depending on various DEM resolution values. Similar to Figure 15a, the variation in the efficiency was very small when the DEM resolution values were 5 and $40 \mathrm{~m}$. However, the change in the efficiency 
was very large with the constant parameter set depending on the 80,160, and $300 \mathrm{~m}$ DEM resolution values. Figure 15 shows that the combination of the input parameters and DEM resolution smaller than $40 \mathrm{~m}$ was not sensitive, which implied that the estimated topographic index, which was the area of the slope per unit contour length divided by the slope of the surface, was similarly smaller in the $40 \mathrm{~m}$ DEM grid cell size. This analysis agreed with that shown in Figures 4 and 5 . The frequencies of the topographic indexes of the $40 \mathrm{~m}$ DEM grid cell size shown in Figures 4 and 5 were slightly different from those of the 5 and $20 \mathrm{~m}$ DEM grid cell size. Therefore, the result suggested that at least the $40 \mathrm{~m}$ resolution showed reliable results with the variation in the input parameters in the TOPMODEL application to the Dongkok and Ieemokjung watersheds. The proposed resolutions in this study were similar to the good-performance resolutions DEM that used $30 \mathrm{~m}$ resolution [40], greater than $10 \mathrm{~m}$ resolution [35], or smaller than $100 \mathrm{~m}$ resolution [37,41]. However, it is necessary to investigate resolutions that provide similar results as this study to the different characteristics of watersheds or to other hydrological models.

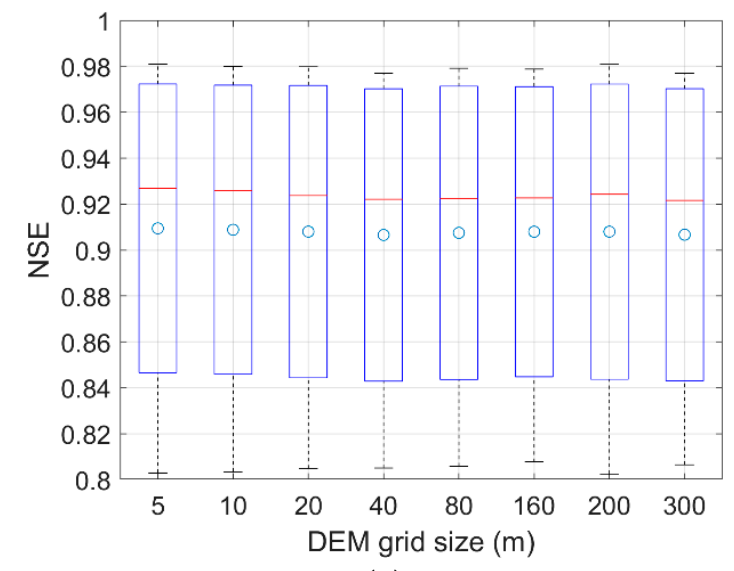

(a)

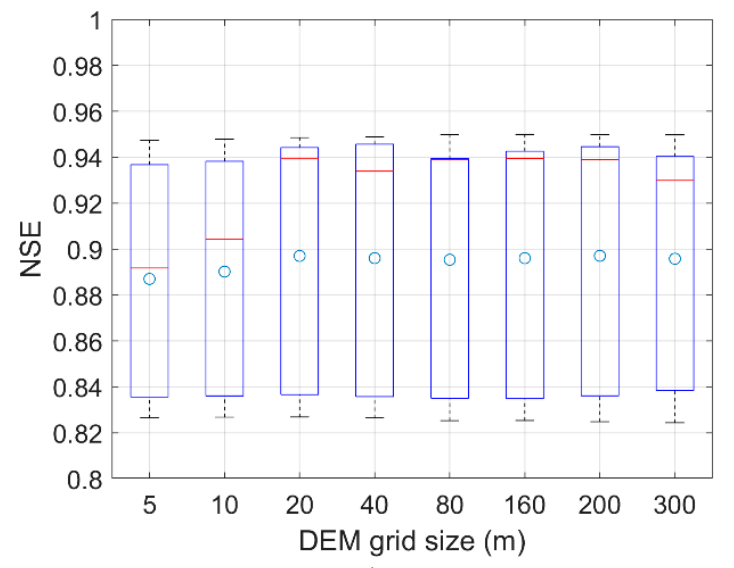

(b)

Figure 14. Results obtained using the optimized input parameters depending the DEM resolution for all Rainfall-runoff events. (a) Dongkok watershed. (b) Ieemokjung watershed.

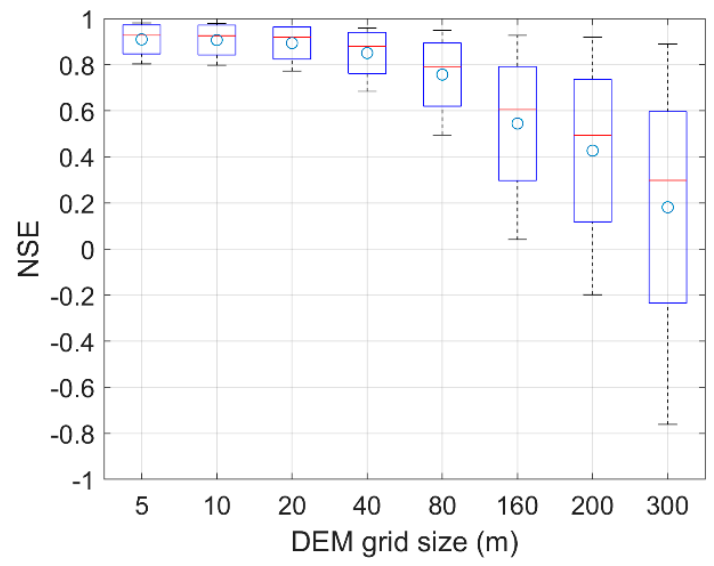

(a)

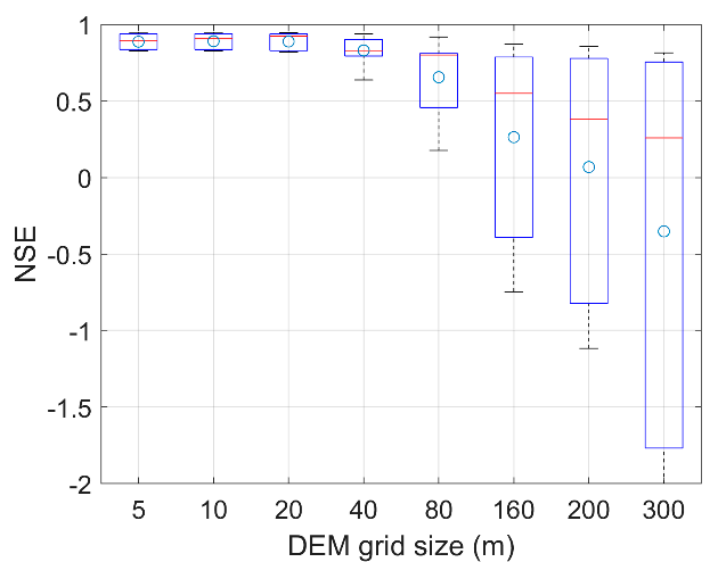

(b)

Figure 15. NSE (Nash-Sutcliffe efficiency) changes based on the resolution of the DEM grid cell size with constant parameter sets. (a) Dongkok watershed. (b) Ieemokjung watershed.

\section{Conclusions}

This study has applied TOPMODEL to two mountainous watersheds, namely, Dongkok and Ieemokjung watersheds, which are representative IHP watersheds in South Korea. This study investigated TOPMODEL runoff optimizations that depend on the resolution of the DEM grid cell size and analyzed the effects of DEM resolution using fixed input parameter sets. Further, this work 
combined the resolution of the DEM grid cell size and optimized input parameter sets and proposed the most reliable DEM grid-size resolution for TOPMODEL in the two mountainous watersheds. The optimized parameter results represent that an exponential storage parameter among calibrating input parameter is the most sensitive parameter based on TOPMODEL efficiencies.

The estimated hydrographs obtained by TOPMODEL based on well-optimized parameters that depend on each resolution of the DEM grid cell size were very similar to the observed runoff, regardless of the DEM resolution (up to $300 \mathrm{~m}$ in this study), which demonstrated that DEM resolution does not affect the runoff estimation when the input parameters are well optimized. In addition, this study analyzed the DEM resolution effects by applying a fixed parameter set and found that the NSE of the estimated runoff in TOPMODEL decreased as the DEM resolution increased. The estimated runoff results depending on the different optimized input parameters in both the Dongkok and Ieemokjung watersheds were similar to the observed runoff data when the DEM resolution was less than about $40 \mathrm{~m}$. The results of this study imply that reliable DEM grid size depending on experimental watersheds can be evaluated in TOPMODEL. However, these results have limitations in that the reliable DEM grid cell size was evaluated using only one watershed model and two study watersheds. For future studies, it is necessary to describe more about the relations among contributing area, input parameters, and DEM resolution with rainfall events, because those relations have not been clarified. Also, it is necessary to apply different scales of watersheds and watershed models to support the relationship between reliable DEM resolution and watershed characteristics in this study.

Author Contributions: Conceptualization, D.P. and K.J.; Funding acquisition, D.P.; Investigation, D.P., H.-J.F., J.-J.Z., S.-E.O. and K.J.; Methodology, D.P. and M.-J.U.; Writing—review \& editing, D.P. and K.J.

Funding: This research was supported by Basic Science Research Program through the National Research Foundation of Korea (NRF) funded by the Ministry of Education (No. 2019R1A2C1007447) and was written as part of Konkuk University's research support program for its faculty on sabbatical leave in 2019.

Conflicts of Interest: The authors declare no conflict of interest.

\section{References}

1. Beven, K.J.; Kirby, M.J. A physically based variable contributing area model of basin hydrology. Hydrol. Sci. Bull. 1979, 24, 43-69.

2. Güntner, A.; Uhlenbrook, S.; Seibert, J.; Leibundgut, C. Multi-criterial validation of TOPMODEL in a mountainous catchment. Hydrol. Process. 1999, 13, 1603-1620. [CrossRef]

3. Dolcine, L.; Andrieu, H.; Sempere-Torres, D.; Creutin, D. Flash flood forecasting with coupled precipitation model in mountainous Mediterranean basin. J. Hydrol. Eng. 2001, 6, 1-10. [CrossRef]

4. Huang, J.-C.; Lee, T.-Y.; Kao, S.-J. Simulating typhoon-induced storm hydrographs in subtropical mountainous watershed: An integrated 3-layer TOPMODEL. Hydrol. Earth Syst. Sci. 2008, 5, 1101-1135. [CrossRef]

5. Jeziorska, J.; Niedzielski, T. Applicability of TOPMODEL in the mountainous catchments in the upper Nysa Kłodzka River basin (SW Poland). Acta Geophys. 2018, 66, 203-222. [CrossRef]

6. Xue, L.; Yang, F.; Yang, C.; Wei, G.; Li, W.; He, X. Hydrological simulation and uncertainty analysis using the improved TOPMODEL in the arid Manas River basin. China Sci. Rep. 2018, 8, 452. [CrossRef]

7. Liang, X.; Lettenmaier, D.P.; Wood, E.F.; Burges, S.J. A simple hydrologically based model of land surface water and energy fluxes for general circulation models. J. Geophys. Res. Atmos. 1994, 99, 14415-14428. [CrossRef]

8. Park, D.; Markus, M. Analysis of a changing hydrologic flood regime using the Variable Infiltration Capacity model. J. Hydrol. 2014, 515, 267-280. [CrossRef]

9. Devia, G.K.; Ganasri, B.P.; Dwarakish, G.S. A review on hydrological models. Aquatic Procedia 2015, 4, 1001-1007. [CrossRef]

10. Beven, K.J.; Wood, E.F. Catchment geomorphology and the dynamics of runoff contributing areas. J. Hydrol. 1983, 65, 139-158. [CrossRef]

11. Sivapalan, M.; Wood, E.F.; Brven, K.J. On hydrologic similarity: 3, A dimensionless flood frequency model using a generalized geomorphic unit hydrograph and partial area runoff generation. Water Resour. Res. 1990, 25, 43-58. [CrossRef] 
12. Wolock, D.M.; Hornberger, G.M.; Musgrove, T. Topographic controls on episodic streamwater acidification in Wales. J. Hydrol. 1990, 115, 243-259. [CrossRef]

13. Wolock, D.M.; Price, C.V. Effects of digital elevation map scale and data resolution on a topography-based watershed model. Water Resour. Res. 1994, 30, 3041-3052. [CrossRef]

14. Franchini, M.; Wending, J.; Obled, C.; Todini, E. Physical interpretation and sensitivity analysis of the TOPMODEL. J. Hydrol. 1996, 175, 293-338. [CrossRef]

15. Saulnier, G.M.; Obled, C.; Beven, K.J. Analytical compensation between DTM grid resolution and effective values of saturated hydraulic conductivity within the TOPMODEL framework. Hydrol. Process. 1997, 11, 1331-1346. [CrossRef]

16. Saulnier, G.M.; Beven, K.J.; Obled, C. Digital elevation analysis for distributed hydrological modeling: Reducing scale dependence in effective hydraulic conductivity values. Water Resour. Res. 1997, 33, $2097-2101$. [CrossRef]

17. Quinn, P.F.; Beven, K.J.; Lamb, R. The $\ln (\mathrm{a} / \operatorname{tanb})$ index: How to calculate it and how to use it within the TOPMODEL framework. Hydrol. Process. 1995, 9, 161-182. [CrossRef]

18. Hancock, G.R. The use of digital elevation models in the identification and characterization of catchments over different grid scales. Hydrol. Process. 2005, 19, 1727-1749. [CrossRef]

19. Nourani, V.; Roughani, A.; Gebremichael, M. TOPMODEL capability for Rainfall-runoff modeling of the Ammameh watershed at different time scales using different terrain algorithms. J. Urban Environ. Eng. 2011, 5, 1-15. [CrossRef]

20. Nourani, V.; Zanardo, S. Wavelet-based regularization of the extracted topographic index from high-resolution topography for hydro-geomorphic applications. Hydrol. Process. 2014, 28, 1345-1357. [CrossRef]

21. Sörensen, R.; Seibert, J. Effects of DEM resolution on the calculation of topographical indices: TWI and its components. J. Hydrol. 2007, 347, 79-89. [CrossRef]

22. Azizian, A.; Shokoohi, A. Investigation of the Effects of DEM Creation Methods on the Performance of a Semidistributed Model: TOPMODEL. J. Hydrol. Eng. 2015, 20, 05015005. [CrossRef]

23. Lin, K.; Zhang, Q.; Chen, X. An evaluation of impacts of DEM resolution and parameter correlation on TOPMODEL modeling uncertainty. J. Hydrol. 2010, 394, 370-383. [CrossRef]

24. Ministry of Land, Transport and Maritime Affairs (MLTMA). International Hydrological Programme Report; Ministry of Land, Transport and Maritime Affairs (MLTMA): Sejong, Korea, 2001. (In Korean)

25. Bae, D.-H.; Kim, J.-H.; Kwon, W.-T. A Feasibility Study of TOPMODEL for a Flood Forecasting Model on a Single Watershed. J. Korean Water Resour. Assoc. 2000, 33, 87-97. (In Korean)

26. Ambroise, B.; Beven, K.J.; Freer, J. Toward a generalization of the TOPMODEL concepts: Topographic indices of hydrological similarity. Water Resour. Res. 1996, 32, 2135-2145. [CrossRef]

27. Grabs, T.; Seibert, J.; Bishop, K.; Laudon, H. Modeling spatial patterns of saturated areas: A comparison of the topographic wetness index and a dynamic distributed model. J. Hydrol. 2009, 373, 15-23. [CrossRef]

28. Qin, C.Z.; Zhu, A.X.; Pei, T.; Li, B.L.; Scholten, T.; Behrens, T.; Zhou, C.H. An approach to computing topographic wetness index based on maximum downslope gradient. Precis. Agric. 2011, 12, 32-43. [CrossRef]

29. Buchanan, B.P.; Fleming, M.; Schneider, R.L.; Richards, B.K.; Archibald, J.; Qiu, Z.; Walter, M.T. Evaluating topographic wetness indices across central New York agricultural landscapes. Hydrol. Earth Syst. Sci. 2014, 18, 3279-3299. [CrossRef]

30. Pourali, S.H.; Arrowsmith, C.; Chrisman, N.; Matkan, A.A.; Mitchell, D. Topography wetness index application in flood-risk-based land use planning. Appl. Spat. Anal. Policy 2016, 9, 39-54. [CrossRef]

31. Tada, A.; Namihira, A.; Tanakamaru, H.; Hata, T. Application of TOPMODEL to Long-and Short-term Runoff of Small Forested Catchment. J. Jpn. Soc. Hydrol. Water Resour. 2002, 15, 399-412. (In Japanese) [CrossRef]

32. Cho, I.R. Runoff Analysis Using TOPMODEL. Master's Thesis, Ulsan University, Ulsan, Korea, 1998. (In Korean)

33. Lee, G.S. Improvement and Application of TOPMODEL to Estimate Nonpoint Source Pollution Loadings in Small Basin. Master's Thesis, Seoul National University, Seoul, Korea, 1998. (In Korean)

34. Nash, J.E.; Stutcliffe, J.V. River flow forecasting through conceptual models, Part I-a discussion of principles. J. Hydrol. 1970, 10, 282-290. [CrossRef]

35. Zhang, W.; Montgomery, D.R. Digital elevation model grid size, landscape representation, and hydrologic simulations. Water Resour. Res. 1994, 30, 1019-1028. [CrossRef] 
36. Beven, K.J.; Kirkby, M.J.; Schofield, N.; Tagg, A.F. Testing a physically-based flood forecasting model (TOPMODEL) for three UK catchments. J. Hydrol. 1984, 69, 119-143. [CrossRef]

37. Brasington, J.; Richards, K. Interactions between model predictions, parameters and DTM scales for TOPMODEL. Comput. Geosci. 1998, 24, 299-314. [CrossRef]

38. Fernández-Pato, J.; Caviedes-Voullième, D.; García-Navarro, P. Rainfall/runoff simulation with 2D full shallow water equations: Sensitivity analysis and calibration of infiltration parameters. J. Hydrol. 2016, 536, 496-513.

39. Sanzana, P.; Gironás, J.; Braud, I.; Hitschfeld, N.; Branger, F.; Rodriguez, F.; Fuamba, M.; Romero, J.; Vargas, X.; Muñoz, J.F.; et al. Decomposition of 2D polygons and its effect in hydrological models. J. Hydroinform. 2018, 21, 104-122. [CrossRef]

40. Gumindoga, W.; Rwasoka, D.T.; Murwira, A. Simulation of streamflow using TOPMODEL in the Upper Save River catchment of Zimbabwe. Phys. Chem. Earth Parts A/B/C 2011, 36, 806-813. [CrossRef]

41. Manfreda, S.; Leo, M.D.; Sole, A. Detection of flood-prone areas using digital elevation models. J. Hydrol. Eng. 2011, 16, 781-790. [CrossRef]

(C) 2019 by the authors. Licensee MDPI, Basel, Switzerland. This article is an open access article distributed under the terms and conditions of the Creative Commons Attribution (CC BY) license (http://creativecommons.org/licenses/by/4.0/). 